\title{
PENGARUH KECERDASAN EMOSIONAL, KECERDASAN SPIRITUAL DAN MOTIVASI BERPRESTASI TERHADAP KEMANDIRIAN SANTRIWAN-SANTRIWATI MUHAMMADIYAH BOARDING SCHOOL PRAMBANAN YOGYAKARTA
}

\author{
Ahmad Bahrudin Siregar \\ Program Pasca Sarjana Magister Studi Islam \\ Universitas Muhammadiyah Yogyakarta \\ E-mail: arisbahruddin@gmail.com
}

\begin{abstract}
Abstrak
Tujuan penelitian untuk mengenalisa seberapa besar pengaruh kecerdasan emosional, kecerdasan spiritual dan motivasi berprestasi terhadap kemandirian santriwan dan santriwati Pondok Pesantren Modern Muhammadiyah Boarding school Prambanan Yogyakarta. Penelitian ini berjenis penelitian lapangan dengan menggunakan pendekatan kuantitatif dan bersifat korelasional. Populasinya seluruh santriwan dan santriwati Pondok Pesantren Modern Muhammadiyah Boarding school Prambanan Yogyakarta dan sampel penelitian ini 255 siswa. Teknik pengumpulan data menggunakan kuisioner angket, wawancara, observasi dan dokumentasi. Hasil penelitian yaitu (1) pengaruh kecerdasan emosional terhadap kemandirian santriwan sebesar $41,3 \%$ dan santriwati sebesar 33,9\%. (2) pengaruh kecerdasan spiritual terhadap kemandirian santriwan sebesar $34,3 \%$ dan santriwati sebesar $25,5 \%$. (3) pengaruh motivasi berprestasi terhadap kemandirian santriwan sebesar 64,3\% santriwati sebesar 50,9\%. (4) pengaruh kecerdasan emosional, kecerdasan spiritual dan motivasi berprestasi terhadap kemandirian santriwan sebesar $67,8 \%$ dan santriwati sebesar $55,9 \%$.
\end{abstract}

Kata kunci: kecerdasan emosional, kecerdasan spiritual , motivasi berprestasi dan kemandirian

\begin{abstract}
The purpose of this study is to recognize how much influence of emotional intelligence, spiritual intelligence and achievement motivation towards the independence of students and santriwati Modern Boarding School Muhammadiyah Boarding school Prambanan Yogyakarta. This research is manifold field research by using quantitative approach and correlational. The population of all santriwan and santriwati of Modern Boarding School Muhammadiyah Boarding School Prambanan Yogyakarta and sample of this research are 255 students. Data collection techniques used questionnaires questionnaires, interviews, observation and documentation. The result of this research are (1) the influence of emotional intelligence on students independence by $41,3 \%$ and santriwati $33,9 \%$. (2) the influence of spiritual intelligence on the independence of students by $34.3 \%$ and $25.5 \%$ santriwati. (3) the influence of achievement motivation on the independence of santriwan is $64,3 \%$ santriwati equal to $50,9 \%$. (4) the influence of emotional intelligence, spiritual intelligence and achievement motivation to the independence of santriwan by $67.8 \%$ and santriwati of $55.9 \%$.
\end{abstract}

Keywords: emotional intelligence, spiritual intelligence, achievement motivation and selfreliance

Info Artikel

Diterima Maret 2018, disetujui April 2018, diterbitkan Juni 2018

Dipublikasikan Oleh: Program Studi Bimbingan dan Konseling 


\section{PENDAHULUAN}

Pendidikan merupakan hal yang sangat penting dalam kehidupan, sehingga tidak dapat dipisahkan dari kehidupan manusia. Karena pendidikan sangat dibutuhkan setiap manusia untuk menunjang perannya di masa yang akan datang. UU RI No. 20 tentang Sistem Pendidikan Nasional pasal 3 menyebutkan bahwa:

Pendidikan nasional ..., bertujuan untuk berkembangnya potensi peserta didik agar menjadi manusia yang beriman dan bertakwa kepada Tuhan Yang Maha Esa, berakhlak mulia, sehat, berilmu, cakap, kreatif, mandiri, dan menjadi warga negara yang demokratis serta bertanggungjawab".

Berdasarkan regulasi di atas, tujuan pendidikan nasional adalah untuk mengembangkan potensi peserta didik, salah satunya adalah menjadikannya mandiri. Familia mengungkapkan seseorang dikatakan mandiri apabila "orang tersebut mampu mengarahkan dan mengurus diri sendiri”. Selannnjutnya, Desmita menjelaskan bahwa sikap mandiri atau kemandirian merupakan "kemampuan untuk mengendalikan dan mengatur pikiran, perasaan dan tindakan sendiri secara bebas serta berusaha sendiri untuk mengatasi perasaan-perasaan malu dan keragu-raguan". Artinya kemandirian merupakan suatu kecenderungan untuk mengoptimalkan kemampuan diri sendiri dalam rangka menyelesaikan suatu masalah secara bebas, progresif, dan penuh dengan inisiatif. Oleh karena itu, "individu yang mandiri adalah individu yang berani mengambil keputusan dilandasi oleh pemahaman akan segala konsekuensi dari tindakannya".

Kemudian Steinberg membagi kemandirian dengan tiga bentuk yaitu: Kemandirian emosi yang berhubungan dengan kemampuan seseorang untuk melepaskan ketergantungan dirinya terhadap orangtua atau orang dewasa lainnya, kemandirian tingkahlaku yang berkaitan dengan kemampuan membuat keputusan dan bertindak sesuai dengan keputusannya dan kemandirian nilai yang meliputi kebebasan memaknai prinsip benar salah, baik buruk tanpa pengaruh dari oranglain.

Salain itu, tujuan pendidikan nasional di atas juga merupakan rumusan mengenai kualitas manusia yang harus dikembangkan oleh setiap satuan pendidikan di Indonnesia, seperti pendidikan kejuruan, pendidikan kedinasan, pendidikan khusus, pendidikan keagamaan dan lain-lainya. Tentunya dari setiap model dan sistem pendidikan tersebut memiliki ciri khas dan karakter masing-masing yang menjadikan identitas terhadap lembaga pendidikan itu. Diantara beberapa model lembaga pendidikan yang berkembang di Indonesia, satu diantaranya adalah model pondok pesantren.Sejalan dengan tujuan pendidikan nasional, Masyhud dan Khusnurdilo 
menjelaskan bahwa tujuan pendidikan pondok pesantren adalah:

Menciptakan

dan mengembangkan kepribadian muslim, yaitu kepribadian yang beriman dan bertaqwa kepada Tuhan, berakhlak mulia, menjadi pribadi yang bermanfaat dan berkhidmad kepada masyarakat, mampu berdiri sendiri, bebas dan teguh dalam kepribadian, menyebarkan agama dan menegakkan Islam di tengahtengah masyarakat dan mencintai ilmu dalam mengembangkan kepribadian yang muhsin tidak hanya sekedar muslim.

Lebih jelas lagi Sanusi menjelaskan bahwa "pendidikan pondok pesantren telah membuktikan keberhasilannya dalam mencetak santri-santri yang mandiri. Hal ini ini disebabkan karena selama di pondok pesantren, para santri tinggal jauh dari orang tua, sehingga para santri dituntut untuk menyelesaikan semua tugasnya secara mandiri. Sikap mandiri atau kemandirian tersebut didasari sikap disiplin terhadap diri sendiri yang menuntutnya untuk lebih aktif, kreatif dan inovatif'.

Namun fakta di lapangan masih ditemukan beberapa santri memiliki sikap kemandirian yang rendah, seperti yang terjadi di Pondok Pesantren Modern Muhammadiyah Boarding School (MBS) Prambanan Yogyakarta. Sebagaimana yang dikemukakan oleh Arien selaku bagian kema'hadan, beliau mengungkapkan "....masih ada beberapa santri yang kurang mandiri, misalnya kurang percaya diri, kurang menghargai waktu, kurang menertibkan barang-barang pribadi saat di kamar dan kurang bertanggung jawab dalam koordinasi”. Kemudian berdasarkan hasil observasi, peneliti mendapati beberapa santri masih kurang bertanggung jawab terhadap barang-barang nya. Selain itu, terdapat beberapa santri yang kurang menghargai waktu. Misalnya ketika waktu berangkat ke masjid untuk shalat maghrib berjama'ah, terdapat beberapa santri yang tidak menyegerakan dirinya untuk pergi ke masjid.

Fakta tersebut diperkuat dari beberapa hasil penelitian yang telah dilakukan oleh para peneliti terdahulu. Sebagaimana hasil penelitian Diah dkk di salah satu pondok pesantren Jakarta Barat, ditemukan bahwa "...hampir seluruh santri pernah mengalami perasaan tersinggung saat melakukan interaksi dengan temantemannya, menemukan kesulitan dalam memecahkan masalah, mengalami kecemasan yang berlebihan, belum bisa menahan diri saat marah dan kesal...". Selanjutnya hasil penelitian Purwoko dkk di pesantren daerah Jakarta, Jawa Barat, Jawa Tengah dan Jawa timur juga ditemukan bahwa “... santri masih mempunyai kemandirian rendah pada tiga bidang yang meliputi manajemen diri, membantu orang lain, dan 
menolong diri sendiri". Kumudian hasil penelitian Mujiburrohman dkk, menemukan bahwa "santri di pondok pesantren Darul Falah Kudus juga masih mempunyai kecenderungan melakukan kebiasan tidak mau sholat berjamaah, bermain play station, bepergian sampai batas waktu yang ditentukan oleh pesantren, menunggu perintah terdahulu untuk mengikuti jadwal kegiatan pesantren". Temuantamuan di atas, senada dengan pendapat yang dikemukanan oleh Kartadinata, yang menjelaskan bahwa "Ketergantungan disiplin terhadap kontrol luar bukan karena niat yang muncul dari pribadi ikhlas, sikap hidup yang cenderung formalistik atau ritualistik dan tidak konsisten, sikap tidak peduli dengan lingkungan, sikap konformistik yang mengorbankan prinsip merupakan gejala negatif yang menjauhkan individu dari kemandirian".

Basri mengungkapkan bahwa kemandirian dipengaruhi oleh dua faktor yaitu, faktor di dalam diri sendiri (faktor endogen) dan faktor yang terdapat di luar dirinya (faktor eksogen). Artinya, faktor endogen merupakan semua keadaan yang bersumber dari dalam dirinya misalnya bakat, potensi intelektual dan potensi pertumbuhan tubuhnya. Faktor eksogen adalah semua keadaan atau pengaruh yang berasal dari luar dirinya misalnya pola pendidikan dalam keluarga, sikap orang tua terhadap anak, lingkungan sosial ekonomi. Maka dapat diketahui bahwa sikap mandiri atau kemandirian erat hubungannya dengan keadaan dalam diri seseorang yang mendorongnya untuk tidak tergantung kepada orang lain demi pemenuhan kebutuhan hidupnya (faktor endogen).

Faktor endogen adalah salah satu faktor yang berakar dari dalam diri seseorang dan di dalamnya terdapat beberapa elemen yang cukup banyak. Misalnya, kecerdasan emosional, kecerdasan spritual dan motivasi berprestasi yang mempunyai pengaruh terhadap kemandirian individu. Hal itu dapat dibuktikan dari beberapa hasil penelitian terdahulu. Sebagaimana hasil penelitian Baghdad di salah satu SMK di kota Cimahi, Provinsi Jawa Barat, ditemukan bahwa “...semakin tinggi kecerdasan emosional siswa, maka semakin tinggi kemandirian belajar siswa begitupun sebaliknya, sehingga apabila kecerdasan emosional menurun, maka kemandirian belajarpun menurun sebesar...". Selanjutnya hasil penelitian Fairuzah di jurusan manajemen Fakultas Ekonomi UNIM juga ditemukan bahwa "...kecerdasan spiritual mempunyai pengaruh yang signifikan terhadap kemandirian mahasiswa...". Kumudian hasil penelitian Bano, menemukan bahwa "...terdapat pengaruh antara motivasi terhadap kemandirian belajar mahasiswa pascasarjana FKIP-MMP UKSW angkatan 2016".

Berdasarkan pemaparan temuantemuan di atas, kecerdasan emosional, kecerdasan spritual dan motivasi 
berprestasi (faktor endogen) mempunyai pengaruh terhadap kemandirian individu. Oleh karena itu, peneliti tertarik untuk meneliti proses yang melatarbelakangi dan menganalisa seberapa besar pengaruh kecerdasan emosional, kecerdasan spritual dan motivasi berprestasi (faktor endogen)terhadap kemandirian santriwan dan santriwati Muhammadiyah Boarding School Prambanan Yogyakarta.

\section{LANDASAN TEORI}

\section{Kecerdasan Emosional}

Stein dan Book berpendapat bahwa kecerdasan emosional atau Emotional Quotient (EQ) adalah "serangkaian yang memungkinkan kita melapangkan jalan di dunia yang rumit, aspek pribadi, sosial, dan pertahanan dari seluruh kecerdasan, akal sehat yang penuh misteri,dan kepekaan yang penting untuk berfungsi setiap hari”. Kemudian Goleman menyatakan bahwa "kecerdasan emosi merupakan kemampuan emosi yang meliputi kemampuan untuk mengendalikan diri, memiliki daya tahan ketika menghadapi suatu masalah, mampu mengendalikan impuls, memotivasi diri, mampu mengatur suasana hati, kemampuan berempati dan membina hubungan dengan orang lain".

Selanjutnya

Shapiro mendefinisikan kecerdasan emosional sebagai himpunan suatu fungsi jiwa yang melibatkan kemampuan memantau intensitas perasaan atau emosi, baik pada diri sendiri maupun pada orang lain. Individu memiliki kecerdasan emosional tinggi memiliki keyakinan tentang dirinya sendiri, penuh antusias, pandai memilah semuanya dan menggunakan informasi sehingga dapat membimbing pikiran dan tindakan. Segala sesuatu yang dihasilkan emosi tersebut bila dimanfaatkan dengan benar dapat diterapkan sebagai sumber energi yang diperlukan untuk menyelesaikan tugas, mempengaruhi orang lain dan menciptakan hal-hal baru.

Seseorang akan memiliki kecerdasan emosi yang berbeda-beda. Ada yang rendah, sedang maupun tinggi. Dapsari megemukakan ciri-ciri kecerdasan emosi yang tinggi antara lain:

1. Optimal dan selalu berpikir positif pada saat menangani situasisituasi dalam hidup. Seperti menagani peristiwa dalam hidupnya dan menangani tekanan-tekanan masalah pribadi yang dihadapi.

2. Terampil dalam membina emosi diri dan orang lain

3. Optimal pada kecakapan kecerdasan emosi meliputi intensionalitas, kreatifitas, ketangguhan, hubungan antar pribadi, ketidakpuasan konstruktif

4. Optimal pada emosi belas kasihan atau empati, intuisi, kepercayaaan, daya pribadi, dan integritas.

5. Optimal pada kesehatan secara umumkualitas hidup dan kinerja yang optimal. 
John Mayer menerangkan beberapa kualitas-kualitas emosional yang penting bagi keberhasilan. Kualitas-kualitas emosional tersebut antara lain adalah empati, mengungkapkan dan memahami perasaan, mengendalikan amarah, kemandirian, kemampuan menyesuaikan diri, disukai, kemampuan memecahkan masalah antarpribadi, ketekunan, kesetiakawanan, keramahan, sikap terhormat. Selanjutnya, Goleman merinci aspek-aspek kecerdasan emosi secara khusus yaitu mengenali emosi diri, mengelola emosi, , memotivasi diri sendiri, mengenali emosi orang lain, dan membina hubungan".Sedikit berbeda dengan pendapat Goleman, menurut Al-Tridhonanto aspek kecerdasan emosi adalah kecakapanpribadi, kecakapan sosial, keterampilan sosial.

Banyak model-model pelatihan untuk meningkatkan kecerdasan emosi yang disampaikan oleh para pakar. sebagaimanamenurut Gottman, ada lima langkah yang dapat digunakan untuk melatih emosi. Kelima langkah tersebut adalah sebagai berikut:

1. Menyadari emosi anak tersebut

2. Mengenali emosi sebagai peluang untuk menjadi akrab dan untuk mengajar

3. Mendengarkan dengan penuh empati dan menegaskan perasaanperasaan si anak

4. Menolong si anak untuk memberi label emosi-emosi dengan katakata
5. Menentukan batas-batas sambil menolong si anak memecahkan masalahnya.

Berikutnya adalah Jean Wipperman, dia menuliskan ide mengenai bagaimana merangsang kecerdasan emosional dengan sebutan kurikulum sepuluh langkah untuk kebijaksanaan emosional. Langkahlangkah tersebut sebagai berikut:

1. Memprioritaskan kesehatan tubuh

2. Menelusuri perasaan dalam tubuh bukan di otak

3. Membangun otot emosional setiap hari dengan mengambil waktu untuk, fokus pada pengalaman emosional

4. Menerima semua yang dirasakan

5. Membuka hati bagi orang lain

6. Mengambil tindakan dengan melakukan berbagai hal yang membuat diri,merasa berguna

7. Mendengarkan dengan empati

8. Menceritakan bagaimana perasaan kita

9. Menggunakan perubahan sebagai suatu kesempatan untuk tumbuh dewasa

10. Membawa humor kemanapun pergi.

\section{Kecerdasan Spritual}

Zohar dan Marshal mendefinisikan kecerdasan spiritual sebagai kecerdasan untuk menghadapi dan memecahkan persoalan makna dan nilai, yaitu kecerdasan untuk menempatkan perilaku dan hidup manusia dalam konteks makna yang lebih luas dan kaya, kecerdasan untuk 
menilai bahwa tindakan atau jalan hidup seseorang lebih bermakna dibanding dengan yang lain. Selanjuntya Tasmara berpendapat bahwa kecerdasan spiritual adalah kemampuan seseorang untuk mendengarkan hati nuraninya, baik buruk dan rasa moral dalam caranya menempatkan diri dalam pergaulan. Kemudian Sirodz juga mengungkapkan bahwa kecerdasan spiritual adalah kemampuan mengubah situasi bermakna yaitu penemuan diri, menentukan pilihan, merasa istimewa, bertanggung jawab dan transendensi.

Ciri-ciri dari
spiritual yang telah
dengan baik meliputi "mempunangan
kesadaran diri, mempunyai visi, fleksibel, berpandangan holistik, melakukan perubahan, sumber inspirasi dan refleksi diri”. Selanjutnya Tasmara menyebutkan ciri kecerdasan spiritual adalah "merasakan kehadiran allah, berdzikir dan berdoa, memiliki kualitas sabar, cenderung pada kebaikan, memiliki empati yang kuat, berjiwa besar memiliki visi dan bagaimana melayani". Menurut Zohar dan Marshall, aspek-aspek kecerdasan spiritual mencakup kemampuan bersikap fleksibel, cerdas, bermanfaat, kuat, memiliki visi, kesadaran diri, berpikir secara holistik, radikal, serta menjadi pribadi mandiri. Adapun faktor yang mempengaruhi kecerdasan spiritual adalah Sel saraf otak dan Titik Tuhan (God spot) kecerdasan spiritual dapat ditingkatkan dan dikembangkan. Adapun langkahlangkahnya adalah sebagai berikut:

1. Menyadari di mana saya sekarang

2. Merasakan dengan kuat bahwa saya ingin berubah

3. Merenungkan apakah pusat saya sendiri dan apakah motivasi saya yang paling dalam.

4. Menemukan dan mengatasi rintangan

5. Menggali banyak kemungkinan untuk melangkah maju

6. Menetapkan hati saya pada sebuah jalan

7. Tetap menyadari bahwa ada banyak jalan.

\section{Motivasi Berprestasi}

Santrock menjelaskan bahwa motivasi berprestasi merupakan keinginan untuk menyelesaikan sesuatu agar mencapai suatu standar kesuksesan dan untuk melakukan suatu usaha dengan tujuan mencapai kesuksesan. Kemudian Winkel mendefinisikan "motivasi berprestasi adalah daya penggerak dalam diri seseorang untuk memperoleh keberhasilan dan melibatkan diri dalam kegiatan di mana keberhasilannya tergantung pada usaha pribadi dan kemampuan yang dimiliki. Menurut pendapat Lindgren "motivasi berprestasi adalah dorongan untuk berprestasi, yaitu dorongan untuk mengatasi rintangan-rintangan dan memelihara kualitas kerja yang tinggi, bersaing melalui usaha-usaha untuk melebihi perbuatan yang 
lampau dan untuk mengungguli orang lain".

Mc Clelland dan Heckhausen menyatakan bahwa "Motivasi berprestasi adalah motif yang mendorong individu untuk mencapai sukses dan bertujuan berhasil dalam kompetisi dengan beberapa ukuran keberhasilan, yaitu dengan membandingkan prestasinya sendiri sebelumnya maupun dengan prestasi orang lain". Selanjutnya Hall dan Lindzey memberikan batasan "motif berprestasi sebagai dorongan yang berhubungan dengan prestasi yaitu menguasai, mengatur lingkungan sosial atau fisik, mengatasi rintangan dan memelihara kualitas kerja yang tinggi, bersaing melebihi prestasi yang lampau dan mempengaruhi orang lain".

Jadi siswa yang mempunyai motivasi berprestasi akan berusaha sekuat tenaga untuk mengatasi segala hambatan belajar, memelihara kualitas belajar yang tinggi dan bersaing guna melebihi prestasi yang telah dicapainya sendiri maupun prestasi temannya. Dimyati menyebutkan fungsi motivasi sebagai berikut:

1. Menyadarkan kedudukan pada awal belajar, proses dan hasil akhir.

2. Menginformasikan tentang kekuatan usaha belajar.

3. Mengarahkan kegiatan belajar.

4. Membesarkan semangat belajar.

5. Menyadarkan pembelajaran adanya berkesinambungan.
Mc Clelland memberikan gambaran atau karakteristik siswa yang memiliki motivasi berprestasi tinggimeliputi perasaan yang kuat untuk mencapai tujuan, bertangungjawab, evaluatif, mengambil resiko sedang, kreatif dan inovatif, serta menyukai tantangan.untuk mengukur motivasi dapat dilakukan dengan cara mengukur faktor-faktor luar dan Mengukur aspek tingkah laku tertentu yang mungkin menjadi ungkapan dari motif tertentu.

Secara umum ada dua faktor yang mempengaruhi motivasi yaitu "faktor internal, yang terdiri dari fisik dan psikologis individu, Serta faktor eksternal seperti sosial dan non sosial". Lebih teknis lagi Dimyati dan Mudjiono menyebutkan faktor-faktor yang mempengaruhi motivasi belajar pada siswa adalah sebagai berikut adalah "cita-cita atau aspirasi siswa, kemampuan siswa, kondisi siswa, kondisi lingkungan siswa, unsur-unsur dinamis dalam belajar dan pembelajaran, upaya guru dalam membelajarkan siswa”. Adapunbeberapa cara untuk menumbuhkan motivasi berprestasi dalam kegiatan belajar di sekolah. Satu di antaranya seperti yang dikemukakan oleh Sardiman, dia berpendapat bahwa menumbuhkan motivasi berprestasi siswa dapat dilakukan dengan cara "memberikan angka, hadiah, ulangan, hasil, pujian dan hukuman". 


\section{Kemandirian}

Menurut Chaplin "mandiri adalah suatu kondisi dimana seseorang tidak tergantung kepada orang lain dalam menentukan keputusan dan adanya sikap percaya diri". "Mandiri merupakan suatu suasana dimana seseorang mau dan mampu mewujudkan kehendak/keinginan dirinya yang terlihat dalam tindakan atau perbuatan nyata, guna menghasilkan sesuatu demi pemenuhan kebutuhan hidupnya dan sesamanya". Selanjutnya Mustari berpendapat orang yang "mandiri adalah orang yang cukup diri (selfsufficient), yaitu orang yang mampu berfikir dan berfungsi secara independen tidak perlu bantuan orang lain, tidak menolak resiko dan bisa memecahkan masalah, bukan hanya khawatir tentang masalah-masalah yang dihadapinya".

Kemandirian dalam arti psikologis dan mentalis mengundang pengertian keadaan seseorang dalam kehidupannya yang mampu memutuskan atau mengerjakan sesuatu tanpa bantuan orang lain. Belajar mandiri adalah proses menggerakkan kekuatan atau dorongan dari dalam diri individu yang belajar untuk menggerakkan potensi dirinya mempelajari objek belajar tanpa ada tekanan atau pengaruh asing di luar dirinya. Kemudian dalam pandangan Erikson "kemandirian adalah usaha untuk melepaskan diri dari orangtua dengan maksud untuk menemukan dirinya melalui proses mencari identitas ego, yaitu merupakan perkembangan kearah individualitas yang mantap dan berdiri sendiri".

Gea mengatakan bahwa individu dikatakan mandiri apabila memiliki lima ciri, yaitu "percaya diri, mampu bekerja sendiri, menguasai keahlian dan keterampilan yang sesuai dengan kerjanya, menghargai waktu, dan tanggung jawab". Sejalan dengan pendapat tersebut, Desmita mengemukakan orang yang mandiri memiliki ciri-cirihasrat bersaing untuk maju, mampu mengambil keputusan dan inisistif, percaya diri dalam melaksanakan tugas-tugasnya dan bertanggung jawabsebagai. Sedangkan Familia berpendapat anak yang mandiri memiliki ciri khas yaitu, “...mempunyai kecenderungan memecahkan masalah, tidak takut mengambil resiko, percaya terhadap penilaian diri sendiri, mempunyai kontrol yang lebih baik terhadap hidupnya".

Robert Havighurst menyebutkan bahwa kemandirian terdiri dari beberapa aspek, yaitu aspek intelektual, aspek sosial, aspek emosi dan aspek ekonomi: Faktor yang mempengaruhi kemandirian remaja yaitu, "gen atau keturunan orang tua, pola asuh orang tua, sistem pendidikan di sekolah dan sistem kehidupan di masyarakat". Desmita mengemukakan upaya yang dapat dilakukan oleh sekolah untuk mengembangkan kemandirian siswa adalah: 
1. Mengembangkan proses belajar mengajar yang demokratis

2. Mendorong anak untuk berpartisipasi aktif dalam pengambilan keputusan dan dalam berbagai kegiatan sekolah.

3. Memberikan kebebasan kepada anak untuk mengekplorasi lingkungan serta mendorong rasa ingin tahu.

4. Penerimaan positif tanpa syarat kelebihan dan kekurangan anak, tidak membeda-bedakan anak yang satu dengan yang lainnya.

5. Menjalin hubungan yang harmonis dan akrab dengan anak.

Sejalan dengan pendapat di atas Ali dan Asrori mengemukakan ada sejumlah intervensi yang dapat dilakukan untuk mengembangkan kemandirian remaja, yaitupenciptaan partisipasi dan keterlibatan dalam keluarga, penciptaan keterbukaan,penciptaan kebebasan untuk mengeksplorasi lingkungan,penerimaan positif tanpa syarat, empati terhadap remaja dan penciptaan kehangatan hubungan dengan remaja.

HASIL DAN PEMBAHASAN

Tabel 1

Kategori Besaran Pengaruh Kemandirian

\begin{tabular}{|c|c|}
\hline Besaran Pengaruh & Kategori \\
\hline $70,0 \%-100 \%$ & Tinggi \\
\hline $35,0 \%-69,9 \%$ & Sedang \\
\hline $0,1 \%-34,9 \%$ & Rendah \\
\hline
\end{tabular}

Pengaruh Kecerdasan Emosional

Terhadap Kemandirian

Tabel 2

Besar Pengaruh Kecerdasan

Emosional terhadap

KemandirianSantriwan

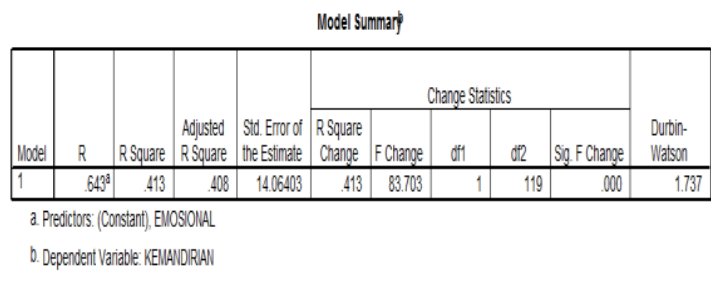

Besaran pengaruh variabel independen terhadap variabel dependen dapat diketahui dari nila $\mathrm{R}$ Square pada tabel 2, yaitu sebesar 0,413. Berarti besaran pengaruh kecerdasan emosional terhadap kemandirian adalah sebesar $41,3 \%$ dan $58,7 \%$ sisanya dipengaruhi oleh faktor lain. Berdasarkan tabel 2, maka besaran pengaruh kecerdasan emosional terhadap kemandirian santriwan terkategori sedang.

Tabel 3

Besar Pengaruh Kecerdasan Emosional terhadap Kemandirian Santriwati

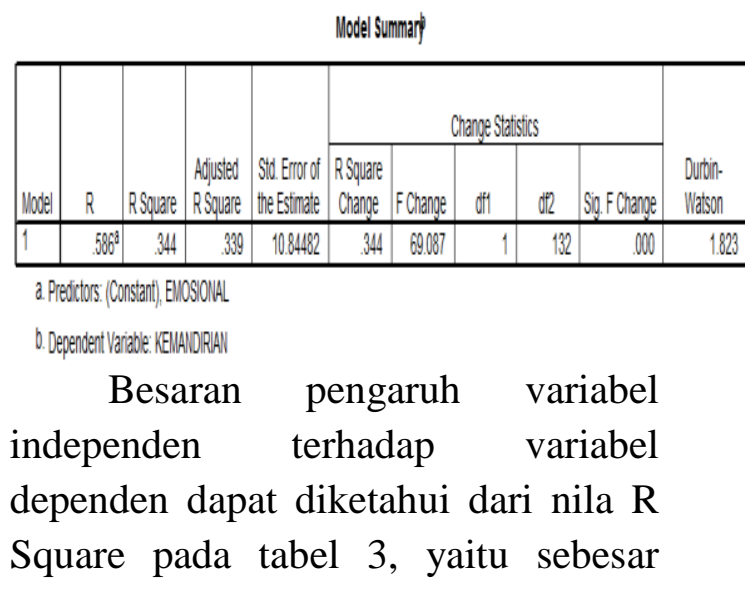


0,339. Berarti besaran pengaruh kecerdasan emosional terhadap kemandirian adalah sebesar 33,9\% dan $66,1 \%$ sisanya dipengaruhi oleh faktor lain. Berdasarkan tabel 1, maka besaran pengaruh kecerdasan emosional terhadap kemandirian santriwati terkategori rendah.

\section{Pengaruh Kecerdasan Spiritual Terhadap Kemandirian}

Tabel 4

Besar Pengaruh Kecerdasan Spiritual terhadap Kemandirian Santriwan

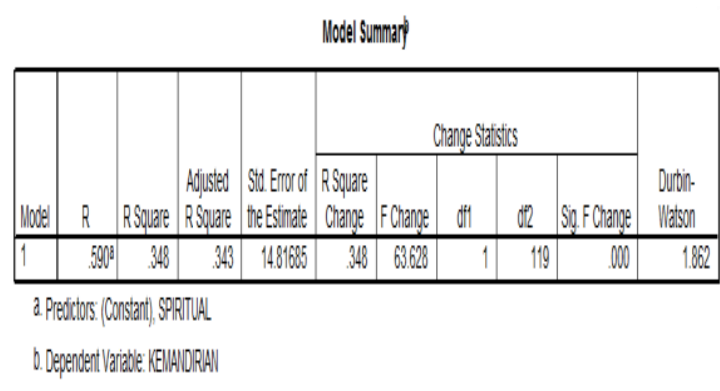

Besaran pengaruh variabel independen terhadap variabel dependen dapat diketahui dari nila $\mathrm{R}$ Square pada tabel 4, yaitu sebesar 0,348. Berarti besaran pengaruh kecerdasan spiritual terhadap kemandirian adalah sebesar 34,3\% dan $65,7 \%$ sisanya dipengaruhi oleh faktor lain. Berdasarkan tabel 1, maka besaran pengaruh kecerdasan spiritual terhadap kemandirian santriwan terkategori rendah.
Tabel 5

\section{Besar Pengaruh Kecerdasan Spiritual terhadap Kemandirian Santriwati}

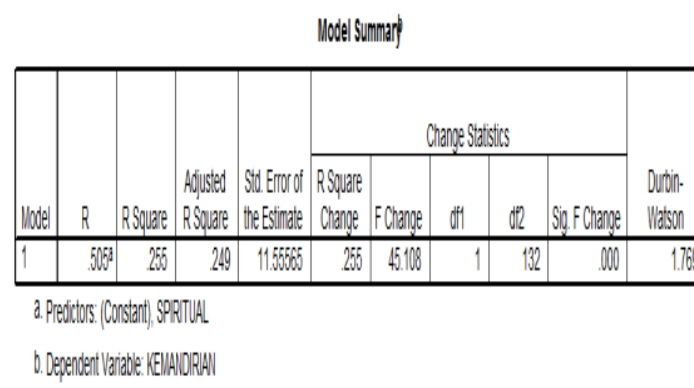

Besaran pengaruh variabel independen terhadap variabel dependen dapat diketahui dari nila $\mathrm{R}$ Square pada tabel 5, yaitu sebesar 0,255 . Berarti besaran pengaruh kecerdasan spiritual terhadap kemandirian adalah sebesar $25,5 \%$ dan $74,5 \%$ sisanya dipengaruhi oleh faktor lain. Berdasarkan tabel 1, maka besaran pengaruh kecerdasan spiritual terhadap kemandirian santriwati terkategori rendah.

\section{Tabel 6}

Besar Pengaruh Motivasi

Berprestasi terhadap Kemandirian Santriwan

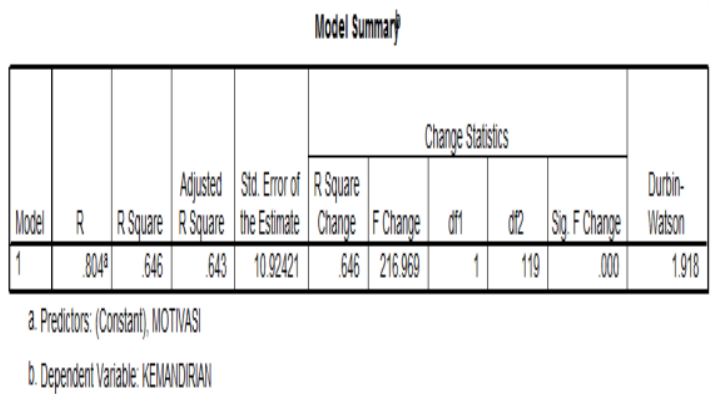

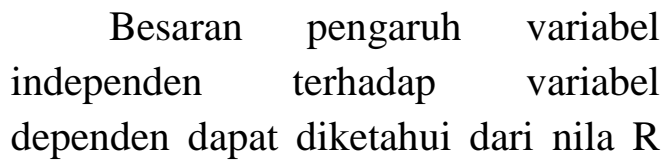


Square pada tabel 6, yaitu sebesar 0,643. Berarti besaran pengaruh motivasi berprestasi terhadap kemandirian adalah sebesar $64,3 \%$ dan $35,7 \%$ sisanya dipengaruhi oleh faktor lain. Berdasarkan tabel 1, maka besaran pengaruh motivasi berprestasi terhadap kemandirian santriwan terkategori sedang.

\section{Table 7}

\section{Besar Pengaruh Motivasi}

Berprestasi terhadap Kemandirian Santriwati

Model Summary

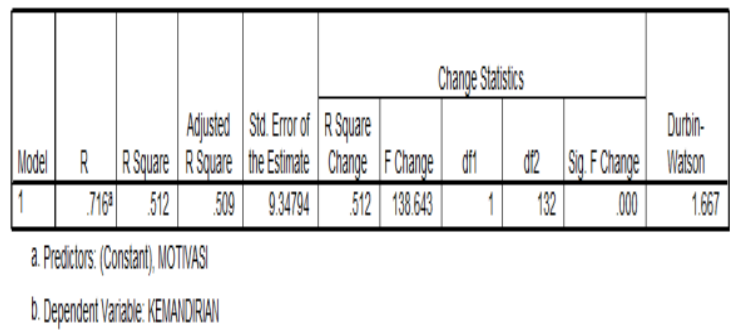

Besaran pengaruh variabel independen terhadap variabel dependen dapat diketahui dari nila $\mathrm{R}$ Square pada tabel 7, yaitu sebesar 0,509. Berarti besaran pengaruh motivasi berprestasi terhadap kemandirian adalah sebesar 50,9\% dan 49,1\% sisanya dipengaruhi oleh faktor lain. Berdasarkan tabel 1, maka besaran pengaruh motivasi berprestasi terhadap kemandirian santriwati terkategori sedang.

$\begin{array}{lll}\text { Pengaruh } & \text { Ketiga } & \text { Variabel } \\ \text { Independent } & \text { Terhadap } & \text { Variabel } \\ \text { Dependent } & & \end{array}$

Tabel 8

Besaran Pengaruh Kecerdasan

Emosional, Kecerdasan Spiritual

dan Motivasi Berprestasi terhadap

Kemandirian Santriwan

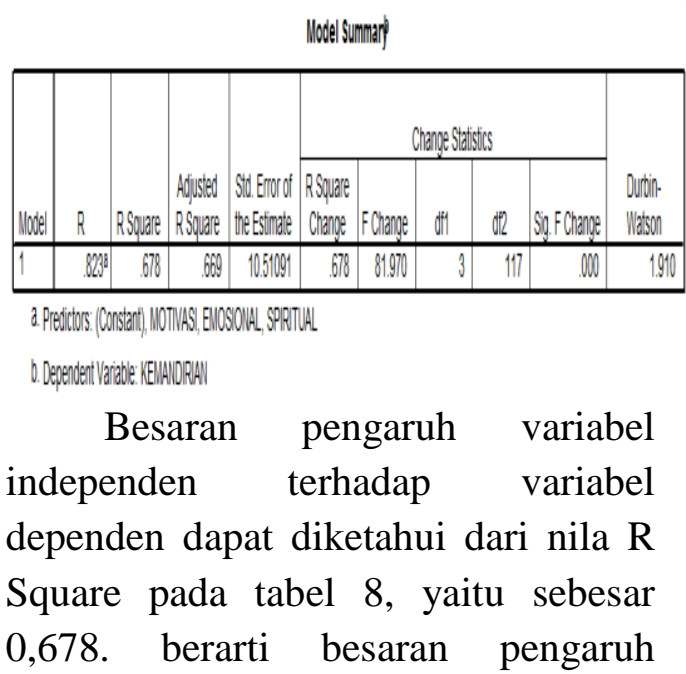

kecerdasan emosional, kecerdasan spiritual dan motivasi berprestasi terhadap kemandirian adalah sebesar $67,8 \%$ dan $32,2 \%$ sisanya dipengaruhi oleh faktor lain. Berdasarkan tabel 1, maka ketiga variabel independent terhadap variabel dependent santriwan terkategori sedang.

\section{Tabel 9}

Besaran Pengaruh Kecerdasan Emosional, Kecerdasan Spiritual dan Motivasi Berprestasi terhadap Kemandirian Santriwati Illodel Summerl

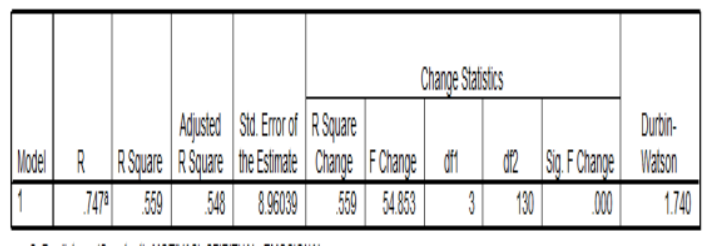

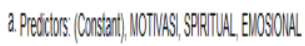

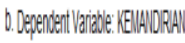


$\begin{array}{ccc}\text { Besaran } & \text { pengaruh } & \text { variabel } \\ \text { independen } & \text { terhadap } & \text { variabel }\end{array}$ dependen dapat diketahui dari nila $\mathrm{R}$ Square pada tabel 9, yaitu sebesar 0,559. berarti besaran pengaruh kecerdasan emosional, kecerdasan spiritual dan motivasi berprestasi terhadap kemandirian adalah sebesar $55,9 \%$ dan $44,1 \%$ sisanya dipengaruhi oleh faktor lain. Berdasarkan tabel 1, maka ketiga variabel independent terhadap variabel dependent santriwati terkategori sedang.

\section{KESIMPULAN DAN SARAN Kesimpulan}

Berdasarkan hasil penelitian yang penulis lakukan dalam penelitian ini, maka dapat disimpulkan bahwa terdapat pengaruh yang sangat signifikan antara kecerdasan emosional, kecerdasan spiritual dan motivasi berprestasi terhadap kemandirian santriwan dan santriwati Pondok Pesantren Modern Muhammadiyah Boarding school Prambanan Yogyakarta baik secara parsial maupun kolektif dengan besaran signifikansi masing-masing sebagai berikut:

1. Pengaruh kecerdasan emosional terhadap kemandirian santriwan sebesar $41,3 \%$ dan santriwati sebesar 33,9\%. Artinya, pengaruh kecerdasan emosional terhadap kemandirian santriwan terkategori sedang dan santriwati terkategori rendah.

2. Pengaruh kecerdasan spiritual terhadap kemandirian santriwan sebesar $34,3 \%$ dan santriwati sebesar 25,5\%. Artinya, pengaruh kecerdasan spiritual terhadap kemandirian santriwan dan santriwati terkategori rendah.

3. Pengaruh motivasi berprestasi terhadap kemandirian santriwan sebesar $64,3 \%$ santriwati sebesar 50,9\%. Artinya, pengaruh motivasi berprestasi terhadap kemandirian santriwan dan santriwati terkategori sedang.

4. Pengaruh kecerdasan emosional, kecerdasan spiritual dan motivasi berprestasi terhadap kemandirian santriwan sebesar $67,8 \%$ dan santriwati sebesar 55,9\%. Artinya, pengaruh ketiga variabel independent terhadap kemandirian santriwan dan santriwati terkategori sedang. Adapun variabel yang memiliki pengaruh paling besar adalah motivasi berprestasi. Maka dapat disimpulkan hubungan kecerdasan emosional, kecerdasan spiritual dan motivasi berprestasi dengan kemandirian merupakan hubungan sebab akibat.

\section{Saran}

Berdasarkan pembahasan dan kesimpulan yang telah dijelaskan, maka peneliti dapat mengajukan beberapa saran yang bertujuan untuk meningkatkan proses pembinaan kecerdasan emosional, kecerdasan spiritual, motivasi berprestasi dan kemandirian. Adapun saran-sarannya sebagai berikut: 
1. Bagi Sekolah

a. Hendaknya melanjutkan dan mengembangkan semua kegiatan yang berkaitan dengan kecerdasan emosional, kecerdasan spiritual, motivasi berprestasi dan kemandirian santriwan dan santriwati PPM Muhammadiyah Boarding school Prambanan Yogyakarta.

b. Hendaknya dapat mengadakan pretest dan posttest yang terkait dengan kecerdasan emosional, kecerdasan spiritual, motivasi berprestasi dan kemandirian santriwan dan santriwati

PPM

Muhammadiyah Boarding school Prambanan Yogyakarta. Agar pihak PPM MBS dapat terus memantau frekuensi variabel-variabel tersebut dengan berkelanjutan.

2. Bagi Penelitian Selanjutnya

Bagi peneliti yang akan melakukan penelitian kuantitatif, hendaknya terlebih dahulu mempersiapkan segala sesuatu dengan matang, agar pelaksanaan penelitian dapat terlaksana dengan baik. Adapun saran untuk penelitian selanjutnya adalah agar hendaknya dapat melakukan kajian penelitian kecerdasan emosional, kecerdasan spiritual, motivasi berprestasi dan kemandirian berdasarkan tinjauan anak nomor berapa atau berdasarakan umur. Kemudian membandingkannya dengan dua, tiga lembaga pendidikan Islam maupun non Islam.

\section{DAFTAR PUSTAKA}

Ali, Muhammad dan Muhammad Asrori. 2012. Psikologi Remaja: Perkembangan Peserta Didik. Jakarta: Bumi Aksara.

Bagdad, Adman Afero. 2016. Peran Kecerdasan Emosional Sebagai Faktor yang Mempengaruhi Kemandirian Belajar Siswa. Jurnal pendidikan manajemen perkantoran. Volume 1, nomor 1.

Bano, Vidriana O. 2016. Pengaruh Lingkungan, Motivasi dan Akses Internet Terhadap Kemandirian Belajar Mahasiswa Pascasarjana. Jurnal. Universitas Kristen Satya Wacana.

Basri, Hasan. 2004. Remaja Berkualitas: Problematika Remaja dan Solusinya. Yogyakarta: Pustaka Pelajar.

Casmini. 2007. Emotional Parenting. Yogyakarta: Nuansa Aksara.

Chaplin. 2014. Kamus Lengkap Psikologi. (Cetakan ke-16). Terjemahan: Kartono Kartini. Jakarta : PT. Grasendo Persada.

Desmita. 2017. Psikologi Perkembangan Peserta Didik. (Cetakan ke-7). Bandung: PT. Remaja Rosdakarya.

Diah, dkk. 2011. Hubungan Antara Kecerdasan Emosi Dengan 
Kepatuhan Dan Kemandirian Satri Remaja. Jurnal Ilmu Keluarga Dan Konsumen. Vol 04. No. 02.

Dimyati dan Mudjiono. 2013. Belajar dan Pembelajaran. (Cetakan ke5). Jakarta: Rineka Cipta.

Fairuzah, Sundari. 2016. Pengaruh Kreativitas dan Kecerdasan Spiritual Terhadap Efikasi Diri dan Kemandirian Mahasiswa. Jurnal Ekonomi dan Dakwah Islam (Al-Tsiqoh). ISSN 25028294. Volume 1.

Familia. 2006. Membuat Prioritas Melatih Anak Mandiri. Yogyakarta: Kanisius.

Gea, Antonius Atosakhi, dkk. 2003. Character Building 1 Relasi dengan Diri Sendiri (edisi revisi). Jakarta: PT Elex Media Komputindo.

Goleman, Daniel. 2009. Emotional Intellegence (Terjemahan : $\mathrm{T}$ Hermaya). Jakarta: PT. Gramedia Pustaka Utama.

Gottman, John. 2003. Kiat-Kiat Membesarkan Anak yang Memiliki Kecerdasan Emosional. Jakarta: Gramedia.

Handoko, Martin. 1992. Motivasi Daya Penggerak Tingkah Laku. Yogyakarta: Kanisius.

Martaniah, Sri Mulyani. 1984. Motif Sosial. Yogyakarta: UGM Press.

Masyhud, Sulthon dan Khusnurdilo. 2003. Manajemen Pondok
Pesantren. Jakarta: Diva Pustaka.

Mujiburrohman, M R, Dewi L S dan Wasino. 2012. Pendidikan Karakter Di Pesantren Darul Falah Kecamatan Jekulo Kabupaten Kudus. Journal Of Educational Social Studies. Vol 1 No. 2.

Mustari, Mohamad. 2011. Nilai Karakter Refleksi untuk Pendidikan Karakter. Yogyakarta: laksbang Pressindo.

Purwoko, dkk. 2007. Hubungan Karakteristik Santri Dengan Persepsi Tentang Kemandirian Di Pondok Pesantren. Jurnal Penyuluhan. Vol 3 no 2

Rachman, Ujang. 2003. Undangundang Republik Indonesia Nomor 20 Tahun 2003 tentang Sistem Pendidikan Nasional.Jakarta. PT. Kloang Klede Putra Timur.

Santrork, J.W. 2003. Adolesence: Perkembangan Remaja. Jakarta :Erlangga.

Sanusi, Uci. 2012. Pendidikan Kemandirian di Pondok Pesantren (Studi Mengenai Realitas Kemandirian di Pondok Pesantren Al-Istiqlal Cianjur dan Pondok Pesantren Bahrul Ulum Tasik Malaya). Jurnal Pendidikan Agama IslamTa'lim. Vol 10 no. 2.

Sardiman, A.M. 2014. Interaksi \& Motivasi Belajar Mengajar. 
(Cetakan ke-22). Jakarta: Raja Grafindo Persada.

Segal, Jeanne. 2000. Melejitkan Kepekaan Emosional. Bandung: Kaifa.

Shapiro, E. L. 2001. Mengajarkan Emotional Intelligence Pada Anak. Jakarta: Gramedia Pustaka

Sirodz, Ahmad. 2010. Aktualisasi Nilai dalam Pengembangan Diri. Jakarta: Evolitera.

Steiberg, L\& Lawrence, R,M. 2004. Hand Book Adolescenct Psychology. Second Edition. Canada: John Wiley\& Sons Inc

Stein, S. J. \& Book, H . E. 2002. Ledakan EQ : 15 Prinsip Dasar Kecerdasan Emosional Meraih Sukses. Terjemahan : Junuarsi dan Murtanto. Bandung: Haifa.

Surya, Hendra. 2003. Kiat mengajak Anak Belajar dan Berprestasi, Jakarta : PT. Gramedia.

Tasmara, Toto. 2001. Kecerdasan Ruhaniah; Transcendental Intellgence: Membentuk Kepribadian Yang Bertanggung Jawab, Professional, Dan Berakhlak. Jakarta: Gema Insani.

Tim Kewirausahaan. 1999. Materi Kewirausahaan. Surakarta: UNS Press.

Winkel, W.S. 2012. Psikologi Pengajaran. (Cetakan ke-15). Yogyakarta. Media Abadi.
Yusuf, Syamsu. 2009. Program Bimbingan dan Konseling di Sekolah. Bandung: Rizqi Press.

Zohar, D \& Marshall, I. 2007. SQ: Kecerdasan Spiritual. (Terjemahan: Rahmani Astusti, dkk). Bandung: PT. Mizan Pustaka. 